\title{
A closer look at Batillipes dicrocercus and new records of Batillipes potiguarensis (Tardigrada: Arthrotardigrada) from the Brazilian coast with comments on intra- and interspecific variability
}

\author{
Érika Santos ${ }^{1,2}$ (D), Edivaldo Gomes Jr (1D), Clélia M. C. da Rocha ${ }^{4}$ (D), \\ Paul J. Bartels ${ }^{5}$ (D) \& Paulo Fontoura', 2 (i)
}

\begin{abstract}
1. Departamento de Biologia, Faculdade de Ciências, Universidade do Porto, Rua Campo Alegre s/n, FC4, 4169-007 Porto, Portugal. (erika.bio@gmail.com; pfontoura@fc.up.pt)

2. MARE, Centro de Ciências do Mar e do Ambiente, ISPA - Instituto Universitário, Rua Jardim do Tabaco 34, $1149-041$ Lisboa, Portugal.

3. Centro de Biociências, Departamento de Biologia Animal, Universidade Federal de Pernambuco. Av Prof. Moraes Rego, 1275, Cid. Universitária, 50670-901 Recife, PE, Brasil. (edivaldolj@@hotmail.com)

4. Departamento de Biologia, Universidade Federal Rural de Pernambuco, Av. Manoel de Medeiros, 52171-900 Recife, PE, Brasil. (cavalcanticlelia@yahoo.com)

5. Department of Biology, Warren Wilson College, Asheville, NC 28815, USA. (pbartels@warren-wilson.edu)
\end{abstract}

Received 04 October 2017

Accepted 12 November 2018

Published 06 December 2018

$10.1590 / 1678-4766 e 2018041$

\begin{abstract}
Batillipes specimens collected in the Southwestern Atlantic Ocean, on the Brazilian Coast (Campos Basin and Potiguar Basin) with a bifurcated caudal appendage similar to B. dicrocercus Pollock, 1970 were assigned to B. potiguarensis Santos, da Rocha, Gomes Jr \& Fontoura, 2017. This species was described as having a roundish caudal protrusion but, as shown in this study, it exhibits intraspecific variability of the morphology of the caudal apparatus. The examination of specimens of B. dicrocercus from the type locality (Massachussetts, U.S.A.) and the analysis of the original description and two subsequent emended descriptions, one from the Gulf of Mexico (U.S.A.) and another from the Mediterranean Sea, used for comparison, revealed important differences among them concerning important taxonomic characters, suggesting that what was considered a single species should now be split into three different species. Therefore, an emended diagnosis of $B$. potiguarensis and comments on the geographic distribution of $B$. dicrocercus are provided, clarifying the taxonomic status of the two species.
\end{abstract}

KEYWORDS. Batillipedidae, Biogeography, meiofauna, Atlantic Ocean, Taxonomy.

RESUMO. Considerações sobre Batillipes dicrocercus e novos registros de Batillipes potiguarensis (Tardigrada: Arthrotardigrada) da costa brasileira, com foco na variabilidade intra- e interespecífica. Exemplares do gênero Batillipes provenientes do sudoeste do Oceano Atlântico na Costa Brasileira (Bacia de Campos e Bacia Potiguar), apresentando um apêndice caudal bifurcado muito semelhante ao de B. dicrocercus Pollock, 1970, foram identificados como pertencendo a B. potiguarensis Santos, da Rocha, Gomes Jr \& Fontoura, 2017, uma espécie caracterizada por exibir uma protrusão caudal arredondada. A identificação baseou-se, como demonstrado neste estudo, que em B. potiguarensis a morfologia do aparato caudal apresenta variabilidade intraespecífica. O exame de exemplares de B. dicrocercus da localidade-tipo (Massachussetts, E.U.A.) e a análise da descrição original e duas descrições subsequentes, uma baseada em exemplares do Golfo do México (U.S.A.) e outra em exemplares do Mar Mediterrâneo, efetuadas para comparação, revelou diferenças importantes no que diz respeito a caracteres taxonômicos relevantes. Este resultado sugere que aquelas descrições correspondem não a uma, mas sim a três espécies distintas. Assim, neste trabalho, completa-se a diagnose de B. potiguarensis e tecem-se comentários sobre a distribuição geográfica de $B$. dicrocercus, contribuindo para contribuindo para o esclarecimento do status taxonômico destas espécies.

PALAVRAS-CHAVE. Batillipedidae, Biogeografia, meiofauna, Oceano Atlântico, Taxonomia.

The interstitial heterotardigrade genus Batillipes was erected with the description of Batillipes mirus Richters, 1909 from the Baltic Sea (Northeastern Atlantic Ocean). Currently, 36 species are known (KRISTENSEN \& MACKNESS, 2000; GuidetTI \& Bertolani, 2005; Degma \& GuidetTI 2007; Degma et al., 2009-2018) from which eight were recorded from Brazil (SANTOS et al., 2017). One of these species, Batillipes dicrocercus was described by PoLlock (1970) from the Northwest Atlantic Ocean. The description was based on specimens collected in intertidal sand at 5-25 $\mathrm{cm}$ depth, from Crane's Beach, Penzance Point, Woods Hole, Massachusetts, United States of America. Subsequently, the species has been recorded from many other localities and reported from different types of sand not only in the intertidal but also in the subtidal zone at depths of about 80-100 m (cf. DA Rocha et al., 2013; KACZMAREK et al., 2015): from the Atlantic Ocean (Gulf of Mexico by McKIRDY, 1975; Brazil by DA RochA et al., 2009, 2013; Galicia, North of Spain by VEIGA et al., 2009); Mediterranean Basin (by D'ADDABBo GALlo et al., 1978, 2007; GRIMALDI DE ZIo et al., 1980, 1983; MaUcCi \& Durante-PASA, 1984; Gallo D'AdDABbo et al. 2000; DE ZIo Grimaldi \& D'AdDABbo Gallo, 2001; DE ZIo GRIMALdi et al. 2003; ACCOGLI et al., 2011); Baltic Sea (Hummon, 1994), and more recently (Miller et al., 
2014) from the Pacific Ocean, the only record outside the Atlantic Basin.

The main attributes characterizing $B$. dicrocercus are the presence of a furcate caudal appendage and prominent lateral body projections between legs III and IV (PoLLOCK, 1970). Traditionally, the morphology of the caudal apparatus was the main distinguishing trait used in the taxonomy of the genus Batillipes (cf. RamazzotTi \& MaUCCI, 1983) but, nowadays, it is recognized that within the genus, the morphology of this character exhibits considerable intraspecific variability (e.g. MCKIRDY, 1975; KRISTENSEN, 1978; Morone De Lucia et al., 1988; Gallo D’AddabBo et al., 2000). Thus, and despite emended descriptions provided by McKirdy (1975) and Gallo D'AdDabBo et al. (2000), imprecisions still subsist and the probability of misidentification concerning $B$. dicrocercus is high. The record from the Baltic Sea (Hummon, 1994) was questioned by ZAWIERUCHA et al. (2015) and attributed to B. noerrevangi Kristensen, 1978, and the erroneous report of MAUCCI \& Durante-Pasa (1984) for the Balearic Sea based on a drawing of a Batillipes with a furcate caudal appendage formerly identified as B. mirus Richters, 1909 by RoDRIGUEZRoda $(1947,1952)$ (see Rubal et al., 2017) are examples of misidentifications.

In having a bifurcate caudal appendage and prominent fourth lateral body projections, Batillipes specimens from the Brazilian Coast were also formerly identified as $B$. dicrocercus (DA Rocha et al., 2009, 2013). However, during a recent survey of marine tardigrades in the Brazilian states of Rio de Janeiro and Rio Grande do Norte mixed populations of Batillipes specimens exhibiting both a bifurcate caudal appendage or a roundish caudal protrusion as observed in $B$. potiguarensis Santos, da Rocha, Gomes Jr \& Fontoura 2017, were collected. This fact demanded a deeper morphological study of B. potiguarensis, a species recently described from Brazil (SANTOS et al., 2017), in order to know if in this species the caudal apparatus also displays intraspecific variability or if the Batillipes from this collection belong to two distinct species. Moreover, a comparative study with $B$. dicrocercus was also necessary because the specimens with furcate caudal apparatuses could be attributed to this species, as it happened in the previously mentioned studies, or could belong to an undescribed species.

Thus, a closer look based on specimens of $B$. dicrocercus from the type locality has been carried out. On one hand, this study allowed us to assign the Brazilian specimens to B. potiguarensis. On the other hand, it revealed important differences concerning reliable taxonomic characters, such as toe arrangement pattern, toe-disc shape, shape and number of lateral body projections, morphology of sensorial appendages and cuticular sculpture, among the original description of B. dicrocercus (PolLock, 1970) and the two subsequent emended descriptions by MCKIRDY (1975) and GALLO D'ADDABBo et al. (2000), suggesting that what was considered a single species should now be split into three different species. Therefore, an emended diagnosis of $B$. potiguarensis and comments on the geographic distribution of $B$. dicrocercus are provided, clarifying the taxonomic status of the two species.

\section{MATERIAL AND METHODS}

Tardigrades of the genus Batillipes were obtained from subtidal sediment samples collected in 2009 by box corer in two localities of the Brazilian Coast (Southwestern Atlantic Ocean): Campos Basin (22 $\left.10^{\circ} \mathrm{S}, 40^{\circ} 20^{\prime} \mathrm{W}\right)$, Rio de Janeiro State, at $25 \mathrm{~m}$ depth, and Potiguar Basin (04 $37^{\prime} \mathrm{S}, 36^{\circ} 45^{\prime} \mathrm{W}$ ), Rio Grande do Norte State, at $5 \mathrm{~m}$ depth. In both localities, the sediment type was represented by bioclastic and litoclastic sands. Samples were preserved in $4 \%$ buffered formaldehyde for later study. At the laboratory, sediments were washed and sieved through a $40 \mu \mathrm{m}$ mesh sieve. Tardigrades were sorted under a dissecting microscope and transferred to microslides with coverslips. Specimens were permanently mounted in pure glycerine with formalin (ca. 1\%) or in glycerol that, after a period of several days to evaporate to glycerine, were sealed with nail varnish. Measurements, given in micrometers $(\mu \mathrm{m})$, and photomicrographs were made under 100x oil immersion, using a Phase Contrast Microscope (PHC) and a Differential Interference Contrast Microscope (DIC), both equipped with digital cameras and using Zen Imaging Software.

For comparison, a paratype and two specimens of $B$. dicrocercus from Pollock's collection (from the type locality: Crane's Beach, Penzance Point, Woods Hole, Massachusetts, U.S.A., deposited in the Department of Biology, Warren Wilson College, Asheville, U.S.A.); specimens attributed to this species from some Northeast Brazilian States [Pernambuco, Ceará and Rio Grande do Norte (deposited in the collection of tardigrades - UFRPE, Brazil)], and the holotype and paratypes of B. potiguarensis (deposited in the collection of the Departamento de Biologia, Faculdade de Ciências, Universidade do Porto, Portugal) were examined. In addition, the original description of $B$. dicrocercus (Pollock, 1970) and subsequent emended descriptions by McKIRDY (1975), based on specimens from the Gulf of Mexico, Florida (U.S.A.), and by GALLO D'ADDABBo et al. (2000), based on specimens from Tremiti Island, Adriatic Sea (Mediterranean Sea) were also used.

\section{RESULTS}

\section{Batillipes potiguarensis Santos, da Rocha, Gomes Jr \& Fontoura, 2017}

Material examined: 35 specimens (18 females, 5 males and 12 juveniles) collected in Campos Basin; and 29 specimens (11 females, 5 males and 13 juveniles) collected in Potiguar Basin, both stations located on the Brazilian Coast.

Description of the examined specimens. Batillipes specimens with distinct head separated from the body by a neck constriction. Scapular region well developed, protruding laterally at the level of the first pair of legs. Body length (caudal apparatus not included) between 105-257 $\mu \mathrm{m}$ (Fig. 
1). Four pairs of blunt ventrolateral body processes are present: a lateral expansion between the head and the first pair of legs; two small lateral processes between the first three pairs of legs and well-developed blunt lateral processes between legs III and IV (Figs 1, 2). Occasionally, the blunt lateral body projections can present a small protruding tip. In some specimens, the lateral projection between the first and second pair of legs is not visible. The caudal apparatus exhibits high variability: in the majority of the specimens it is bifurcated, composed of two spines inserted in a swollen base (Figs 1, 3). In some specimens, the spines are two short spikes of about $9.7 \mu \mathrm{m}$, while other specimens exhibit two longer spines, reaching $23.8 \mu \mathrm{m}$. In a few specimens the caudal apparatus is asymmetric and only a single small spike is present (Fig. 4, 5) or it is restricted to a conspicuous semicircle-shaped protrusion without any spikes or spines at all (Fig. 2,6).

Dorsal cuticle punctated, with evident transverse folds (Fig. 7). Dorso-lateral punctation larger (about 7-10 pillars / $10 \mu \mathrm{m}$, and each pillar with about $1 \mu \mathrm{m}$ high) and more widely spaced than mid-dorsal punctation (about 12-
15 pillars / $10 \mu \mathrm{m})$ (Fig. 7). In the lateral processes between legs III and IV the cuticle is punctated. The ventral surface, also with transverse folds, is more finely punctated.

Head bearing eleven cephalic appendages. The median cirrus, with cirrophore. Internal cirri inserted dorsally on the frontal edge of the head with cirrophores. External cirri with indistinct cirrophores, inserted more ventrally, near the lateral cirri $A$ and primary clavae. The lateral cirrus is located dorsally in relation to the unconstricted, but wrinkled, tubular primary clava. These two appendages share a common pedestal. A van der Land's organ is present at the base of the primary clava that exhibits a terminal pore. In the frontal edge of the head, well-developed papillary secondary clavae are visible (Fig. 1, arrowhead). All cephalic cirri, including external cirri, and lateral cirri have an optically dense dot (dark when observed under PHC) near their swollen tips. Indentations between the external cephalic cirrus and the pedestal bearing the primary clava and lateral cirrus were not seen.

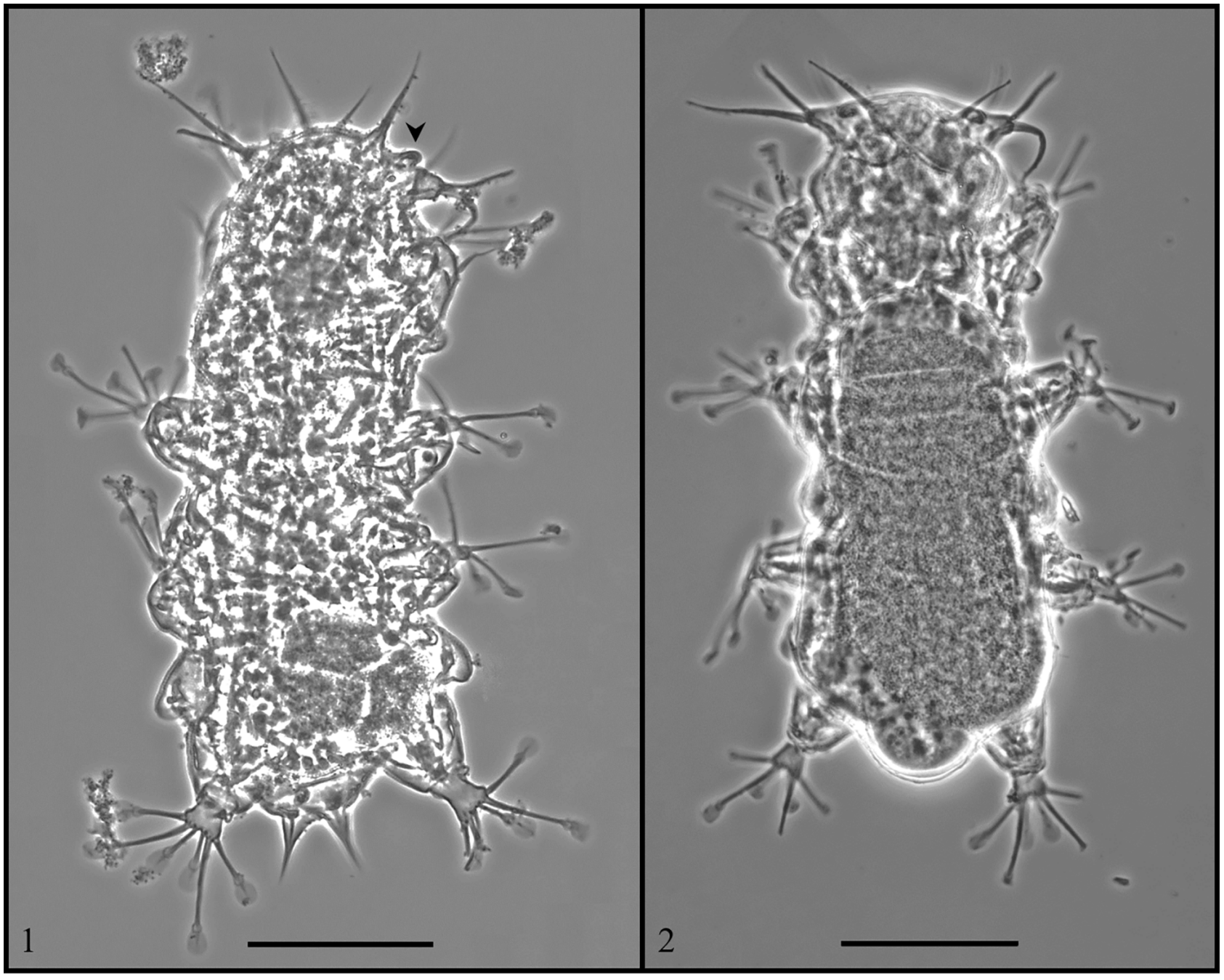

Figs 1,2. Batillipes potiguarensis Santos, Rocha, Gomes Jr \& Fontoura, 2017: 1, specimen from our samples with a bifurcated caudal appendage. The arrowhead shows the well-developed secondary clava; 2, holotype with a rounded caudal protrusion. Scale bars: $50 \mu \mathrm{m}$. 


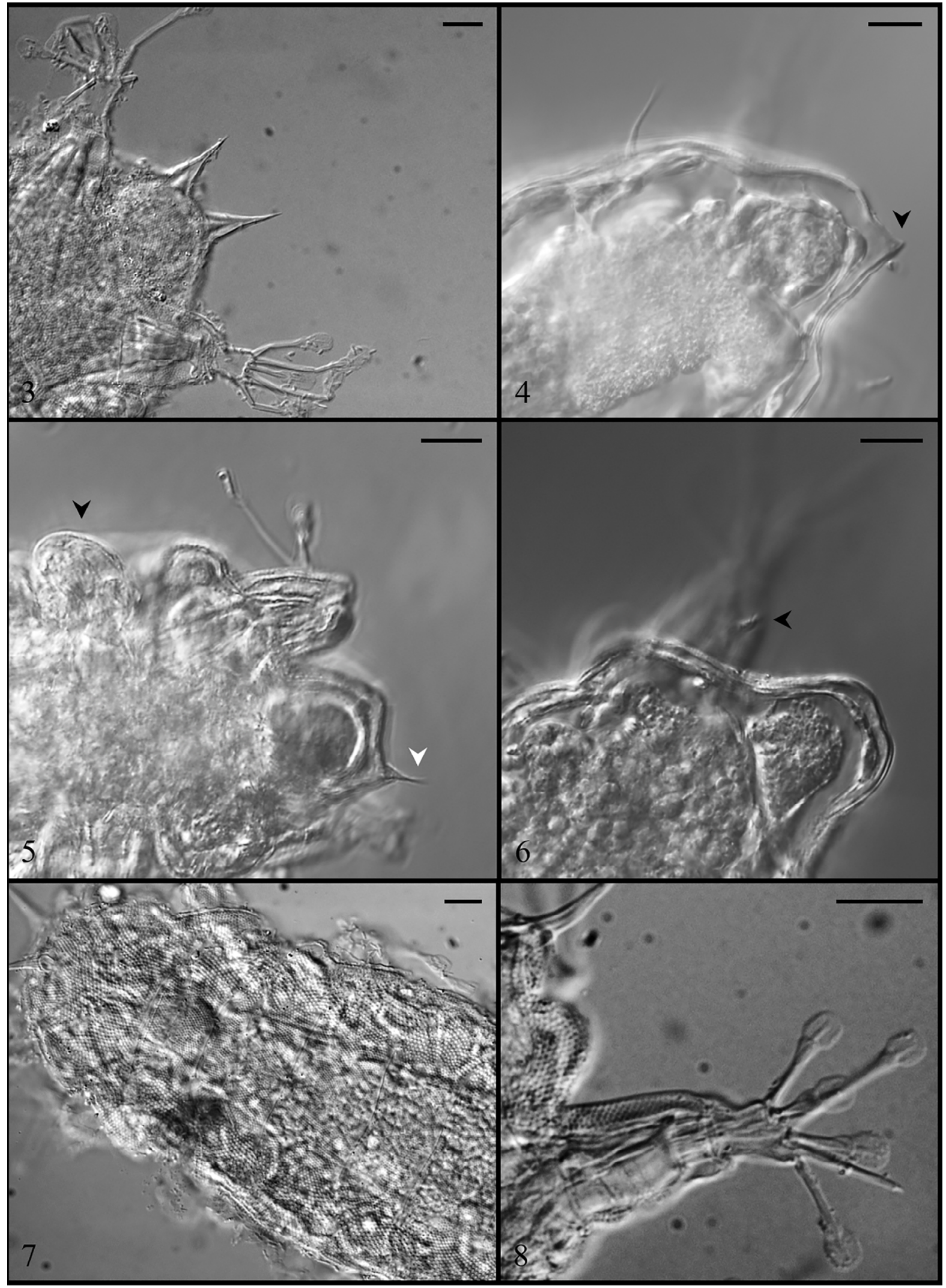

Fig. 3-8. Batillipes potiguarensis Santos, Rocha, Gomes Jr \& Fontoura, 2017: 3, detail of a bifurcated caudal appendage; 4, posterior portion of the body, showing an asymmetric caudal appendage with one short spike only (arrowhead); 5, posterior portion of the body showing an asymmetric caudal appendage with one short spine only (white arrowhead). The black arrowhead shows the blunt lateral projection between legs III-IV; 6, caudal appendage without spines. The sense organ on leg IV is visible (arrowhead); 7, dorsal cuticle with visible folds and punctation not uniformly distributed; 8, detail of the first leg showing the oblique tarsus and spatula-like toe discs. Scale bars: $10 \mu \mathrm{m}$. 
Eye spots not observed. Ventral mouth opening in a protruded cone. Ovoid pharyngeal bulb. Placoids not visible after slide mounting.

Sense organs with swollen tips on legs I and IV and spines on legs II and III. They are similar in length in the first three pair of legs (rarely sense organ on leg I is shorter than on legs II and III). The sense organ on leg IV is consistently the shortest and divided into a cirrophore and a distal portion with a basal van der Land's organ (Fig. 6, arrowhead). Sharply pointed cirri $E$ are present (Fig. 4 ).
Telescopic legs with long toes with spatula-like suction discs with straight frontal edges and with short and thin braces (Figs 1,8). The frontal edge of tarsi is oblique in the first three pair of legs, with toes inserted at different levels (Fig. 8). In these three first pairs of legs, toe 2 is the shortest, toes 3 and 5 are the longest and toes 1, 4 and 6 are medium sized (Fig. 1). In the fourth pair of legs, medial toes 3 and 4 are of equal lengths (toe arrangement pattern A, according to SANTOS et al., 2018). Toes 2 and 5 are the longest and similar to each other; toes 1 and 6 , also similar to each other, are of intermediate length (Figs 1, 2, 8).

Tab. I. Measurements (in $\mu \mathrm{m}$ ) of selected morphological structures of specimens of Batillipes potiguarensis Santos, Rocha, Gomes Jr \& Fontoura, 2017 (SD, Standard deviation. Range refers to the smallest and largest measured specimen/structure; N, number of specimens/structures measured).

\begin{tabular}{|c|c|c|c|c|}
\hline & $\begin{array}{l}\text { Females Adults } \\
\text { This study }\end{array}$ & $\begin{array}{l}\text { Males adults } \\
\text { This study }\end{array}$ & $\begin{array}{l}\text { Juveniles 6-digit } \\
\text { This study }\end{array}$ & $\begin{array}{l}\text { Females } \\
\text { SANTOS et al., } 2017\end{array}$ \\
\hline STRUCTURES & Mean \pm SD (Range) $; \mathrm{N}$ & Mean \pm SD (Range); N & Mean \pm SD (Range); N & Mean \pm SD (Range) $; \mathrm{N}$ \\
\hline Body length (BL) & $\begin{array}{l}195.3 \pm 30.41 \\
(146.3-243.3) ; 29\end{array}$ & $\begin{array}{l}200.4 \pm 38.65 \\
(140.7-261.4) ; 10\end{array}$ & $\begin{array}{l}207.5 \pm 33.70 \\
(125.4-281.2) ; 25\end{array}$ & $\begin{array}{l}184.5 \pm 18.04 \\
(152.2-201.1) ; 6\end{array}$ \\
\hline $\begin{array}{l}\text { BL without caudal } \\
\text { apparatus }\end{array}$ & $\begin{array}{l}179.3 \pm 31.03 \\
(130.0-228.1) ; 29\end{array}$ & $\begin{array}{l}182.6 \pm 38.23 \\
(126.6-243.4) ; 10\end{array}$ & $\begin{array}{l}191.4 \pm 34.55 \\
(105.8-257.0) ; 25\end{array}$ & - \\
\hline Body width & $67.5 \pm 13.61(48.7-99.7) ; 21$ & $66.4 \pm 14.02(53.9-88.9) ; 8$ & $71.9 \pm 15.21(48.2-100.4) ; 15$ & $64.5 \pm 11.26(47.9-78.1) ; 6$ \\
\hline Median cirrus & $18.1 \pm 4.36(10.4-27.0) ; 21$ & $20.5 \pm 4.12(14.7-26.1) ; 7$ & $20.0 \pm 3.17(11.3-26.6) ; 20$ & $16.0 \pm 4.20(10.4-20.5) ; 4$ \\
\hline Internal cirri & $20.4 \pm 3.24(13.3-25.7) ; 25$ & $20.1 \pm 4.18(14.8-25.6) ; 10$ & $21.9 \pm 3.85(12.2-27.8) ; 23$ & $20.5 \pm 1.93(17.0-22.5) ; 6$ \\
\hline External cirri & $17.2 \pm 3.09(10.6-21.6) ; 25$ & $16.8 \pm 2.74(12.6-20.0) ; 8$ & $17.4 \pm 2.85(11.8-21.9) ; 24$ & $16.0 \pm 3.26(12.6-20.1) ; 5$ \\
\hline Lateral cirri $A$ & $33.0 \pm 5.14(24.0-43.3) ; 23$ & $31.4 \pm 8.30(20.0-46.0) ; 9$ & $32.2 \pm 5.41(23.0-44.2) ; 21$ & $28.8 \pm 4.27(22.7-35.8) ; 6$ \\
\hline Primary clavae & $17.9 \pm 3.07(13.0-22.6) ; 27$ & $17.7 \pm 5.13(10.0-26.1) ; 9$ & $18.8 \pm 3.07(12.0-24.9) ; 23$ & $16.5 \pm 2.26(13.4-19.4) ; 6$ \\
\hline Secondary clavae & $4.9 \pm 0.66(3.8-6.5) ; 27$ & $4.5 \pm 1.00(3.1-6.6) ; 8$ & $5.2 \pm 0.92(2.8-6.8) ; 20$ & $5.1 \pm 1.05(3.7-6.2) ; 5$ \\
\hline Cirri $E$ & $19.3 \pm 3.62(14.2-25.4) ; 14$ & $19.0 \pm 4.17(12.3-25.3) ; 6$ & $17.6 \pm 5.25(8.7-27.3) ; 14$ & $20.3 \pm 2.27(17.0-22.8) ; 5$ \\
\hline Leg I sense organ & $9.8 \pm 2.11(5.1-14.0) ; 24$ & $10.1 \pm 2.45(7.6-13.8) ; 7$ & $10.1 \pm 1.79(7.0-12.8) ; 21$ & $10.0 \pm 0.93(8.3-10.9) ; 6$ \\
\hline Leg II sense organ & $10.8 \pm 2.85(5.7-18.6) ; 21$ & $9.7 \pm 3.01(6.9-14.9) ; 7$ & $10.7 \pm 3.28(6.7-19.0) ; 21$ & $9.8 \pm 2.51(7.3-13.5) ; 5$ \\
\hline Leg III sense organ & $10.6 \pm 2.14(7.0-14.5) ; 16$ & $10.2 \pm 3.12(6.7-14.2) ; 6$ & $10.5 \pm 3.63(6.3-17.2) ; 17$ & $10.6 \pm 2.64(7.2-13.1) ; 4$ \\
\hline Leg IV sense organ & $8.9 \pm 1.65(6.1-11.9) ; 26$ & $7.4 \pm 1.15(5.8-9.2) ; 8$ & $9.4 \pm 1.60(6.0-12.3) ; 22$ & $8.4 \pm 1.9(6.6-11.1) ; 6$ \\
\hline Body projection 1 & $7.0 \pm 1.41(4.2-9.5) ; 27$ & $6.2 \pm 2.04(3.4-8.5) ; 8$ & $7.5 \pm 1.58(5.0-10.8) ; 23$ & $6.0 \pm 1.62(3.2-7.8) ; 6$ \\
\hline Body projection 2 & $6.3 \pm 2.13(3.3-11.4) ; 22$ & $5.0 \pm 1.65(3.5-7.7) ; 7$ & $6.3 \pm 0.97(5.0-8.8) ; 18$ & $4.4 \pm 1.47(2.5-6.1) ; 4$ \\
\hline Body projection 3 & $9.0 \pm 2.43(5.2-15.1) ; 27$ & $7.7 \pm 2.50(5.1-12.7) ; 7$ & $9.3 \pm 1.73(6.2-12.3) ; 22$ & $5.5 \pm 1.30(3.8-7.4) ; 5$ \\
\hline Body projection 4 & $10.4 \pm 2.11(6.2-14.7) ; 27$ & $10.5 \pm 2.9(6.6-16.7) ; 9$ & $10.2 \pm 2.44(6.4-15.0) ; 25$ & $9.0 \pm 1.52(6.6-10.8) ; 5$ \\
\hline Body projection 4 width & $15.0 \pm 3.22(10.2-23.8) ; 26$ & $12.2 \pm 3.68(8.5-19.3) ; 8$ & $15.8 \pm 3.12(10.5-21.9) ; 23$ & - \\
\hline Caudal apparatus (spines) & $17.2 \pm 2.65(9.7-23.0) ; 27$ & $17.8 \pm 3.34(13.5-23.8) ; 10$ & $18.3 \pm 4.01(13.3-31.7) ; 22$ & - \\
\hline Legs I-III toe 1 & $13.4 \pm 2.73(9.8-22.2) ; 20$ & $13.5 \pm 3.56(9.7-18.6) ; 7$ & $14.3 \pm 2.26(10.0-18.1) ; 21$ & $10.9 \pm 0.50(10.3-11.5) ; 4$ \\
\hline Toe 2 & $9.2 \pm 1.99(6.8-13.1) ; 14$ & $9.0 \pm 2.47(5.0-11.0) ; 7$ & $10.0 \pm 2.06(5.7-14.7) ; 19$ & $8.2 \pm 1.83(6.5-10.8) ; 4$ \\
\hline Toe 3 & $21.4 \pm 3.10(17.2-28.2) ; 20$ & $19.7 \pm 4.98(14.6-27.1) ; 7$ & $22.3 \pm 3.40(13.7-28.1) ; 23$ & $18.6 \pm 1.06(17.6-19.7) ; 4$ \\
\hline Toe 4 & $13.3 \pm 1.87(11.7-18.1) ; 17$ & $12.6 \pm 3.81(8.5-16.8) ; 7$ & $13.3 \pm 2.52(6.7-17.0) ; 22$ & $11.7 \pm 1.93(9.5-14.2) ; 4$ \\
\hline Toe 5 & $24.2 \pm 3.76(18.2-31.6) ; 18$ & $25.0 \pm 6.02(18.2-32.9) ; 7$ & $25.2 \pm 3.69(17.0-31.8) ; 23$ & $21.8 \pm 1.43(20.6-23.4) ; 3$ \\
\hline Toe 6 & $16.6 \pm 2.52(12.3-21.0) ; 17$ & $16.5 \pm 2.88(12.3-20.5) ; 7$ & $17.1 \pm 2.00(12.2-20.7) ; 21$ & $14.0 \pm 1.38(12.4-15.0) ; 3$ \\
\hline Leg IV toe 1 & $18.6 \pm 2.81(14.6-23.6) ; 20$ & $18.8 \pm 2.80(16.0-23.8) ; 6$ & $19.8 \pm 2.46(16.7-24.3) ; 18$ & - (17.5-20.4); 2 \\
\hline Toe 2 & $26.9 \pm 4.09(19.2-33.5) ; 23$ & $28.0 \pm 4.62(22.1-35.2) ; 6$ & $28.7 \pm 5.37(12.8-39.1) ; 18$ & $-(25.6) ; 1$ \\
\hline Toe 3 & $14.7 \pm 2.84(8.1-20.1) ; 21$ & $15.0 \pm 2.93(11.6-19.8) ; 6$ & $16.0 \pm 2.11(11.0-20.0) ; 16$ & $13.3 \pm 2.70(10.3-15.5) ; 3$ \\
\hline Toe 4 & $14.6 \pm 2.67(8.5-19.0) ; 21$ & $14.9 \pm 2.97(12.2-20.0) ; 6$ & $16.0 \pm 2.80(11.5-24.1) ; 16$ & $13.4 \pm 2.60(10.6-15.7) ; 3$ \\
\hline Toe 5 & $28.1 \pm 4.45(18.0-34.3) ; 22$ & $26.6 \pm 3.02(22.8-30.0) ; 5$ & $28.8 \pm 3.39(20.0-33.4) ; 19$ & $-(25.7-27.5) ; 2$ \\
\hline Toe 6 & $18.9 \pm 2.10(16.0-22.4) ; 20$ & $18.3 \pm 2.72(15.4-22.7) ; 6$ & $19.2 \pm 2.48(15.3-24.0) ; 17$ & $18.8 \pm 1.01(17.1-19.1) ; 3$ \\
\hline Gonopore-Anus & $11.6 \pm 1.93(8.9-16.0) ; 21$ & $5.1 \pm 2.11(3.4-10.4) ; 9$ & - & $9.0 \pm 2.21(6.6-11.1) ; 5$ \\
\hline
\end{tabular}


In females, the gonopore is rosette-shaped delimited by four punctate cuticular platelets, two anterior and two posterior, forming a groove running toward the anus. Males have a circular gonopore with a cuticular crescent shaped fold. Four-toed larvae were not found.

Morphometric data are provided in Table I.

\section{DISCUSSION}

Based on the bifurcated aspect of caudal apparatuses, the examined specimens from Brazil could be easily confused with $B$. dicrocercus. The original description of $B$. dicrocercus, based on specimens from the Northwest Atlantic Ocean (Massachusetts, U.S.A.), is very incomplete and the main trait used to distinguish the species was, in fact, the bifurcated caudal apparatus (POLLOCK, 1970). The scarce information provided in that description and the high intra and interspecific variability of the morphology of the caudal apparatus observed in Batillipes (MCKIRDY, 1975; Gallo D'ADDABBo et al., 2000; KRISTENSEN \& MACKNESS, 2000) justified the subsequent search for a reliable diagnosis. With this goal, McKIRDY (1975) provided an emended diagnosis of B. dicrocercus based on specimens recorded from the Gulf of Mexico (Florida, U.S.A.) and, later on, Gallo D'AdDABBo et al. (2000) redescribed the species using specimens from the Adriatic Sea (Mediterranean Sea). However, a closer look at those emended descriptions, the examination of specimens from the type locality, including a paratype of $B$. dicrocercus, and their comparison with the Brazilian specimens, performed in the present study, showed that these are actually four different Batillipes species that can be distinguished by reliable taxonomic characters (Tab. II).

Specimens from the Gulf of Mexico examined by MCKIRDY (1975), from now on designated B. dicrocercus sensu McKirdy, are very different from the specimens from the Northwestern Atlantic (Massachusetts) described by Pollock (1970), here designated B. dicrocercus sensu stricto (Fig. 9), and clearly belong to a different unnamed species. Contrary to $B$. dicrocercus sensu stricto, the species described by McKIRDY (1975) has frayed cephalic cirri and leg IV sense organs; fourth foot with medial toes of different lengths (toe 4 longer than toe 3 , being toe 3 the

Tab. II. Differences and similarities among populations attributed to Batillipes dicrocercus Pollock, 1970 and B. potiguarensis Santos, Rocha, Gomes Jr \& Fontoura, 2017 (MED, Mediterranean Sea; NEA, Northeast Atlantic; NWA, Northwest Atlantic; SWA, Southwest Atlantic). For quantitative data the values refer to mean \pm standard deviation.

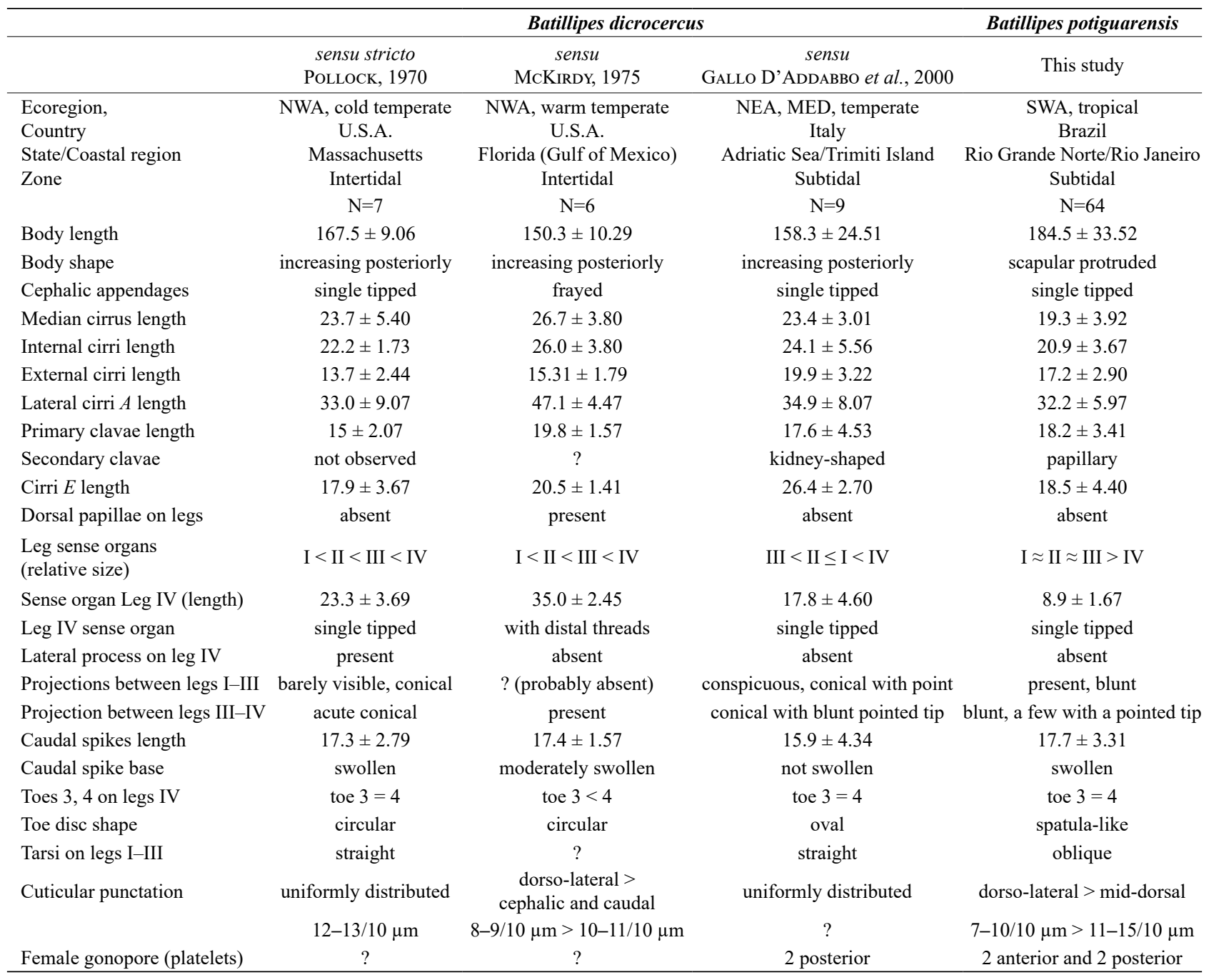


most cephalic, corresponding to toe arrangement pattern B, subgroup B1, according to SANTOS et al. 2018); dorsal cuticle not uniformly punctated (mid-dorsal cuticle with smaller punctations than cephalic and caudal dorsal areas); and a small dorsal papilla is present on each leg. In addition, an evident indentation located on the anterior edge of the head, between external cirri and pedestals bearing primary clava and lateral cirrus $A$, is visible in $B$. dicrocercus sensu McKirdy, and lateral processes on legs IV are absent; while in $B$. dicrocercus sensu stricto the indentation in the frontal edge of the head is barely visible or absent (Fig. 10), and a lateral process is present on the lateral surface of legs IV [this lateral process, although represented in the original drawing, was not described by PoLLock (1970), but its presence was confirmed in this study, see Fig. 11]. Although not considered a relevant distinguishing character, specimens from Florida have slightly longer cephalic appendages (Tab. II) as emphasized by McKIRDY (1975). The two species share the same body shape and both exhibit toes with circular discs. On the other hand, in both species leg sense organs increase in length from legs I to IV, where they are particularly long (Fig. 11). The female gonopore was not described for the specimens from Massachusetts nor for the specimens from Florida. Unfortunately, in the reexamined specimens from Pollock's collection, the gonopore was not visible. Therefore, this important taxonomic character cannot be used for comparison.

Despite having a similar morphometry, qualitative morphological characters of $B$. dicrocercus sensu Gallo D'Addabbo et al. from the Adriatic Sea (GALlo D'AdDABBo et al., 2000), do not match with $B$. dicrocercus sensu stricto either. The presence of peculiar kidney-shaped secondary clavae (secondary clavae are indistinct in B. dicrocercus sensu stricto, see Fig. 10); long toes with elongated ovoid suction discs; conspicuous lateral conical body projections between all pairs of legs (very small and difficult to see, when present, between the first three pairs of legs in B. dicrocercus sensu stricto); evident indentation in the frontal edge of the head;

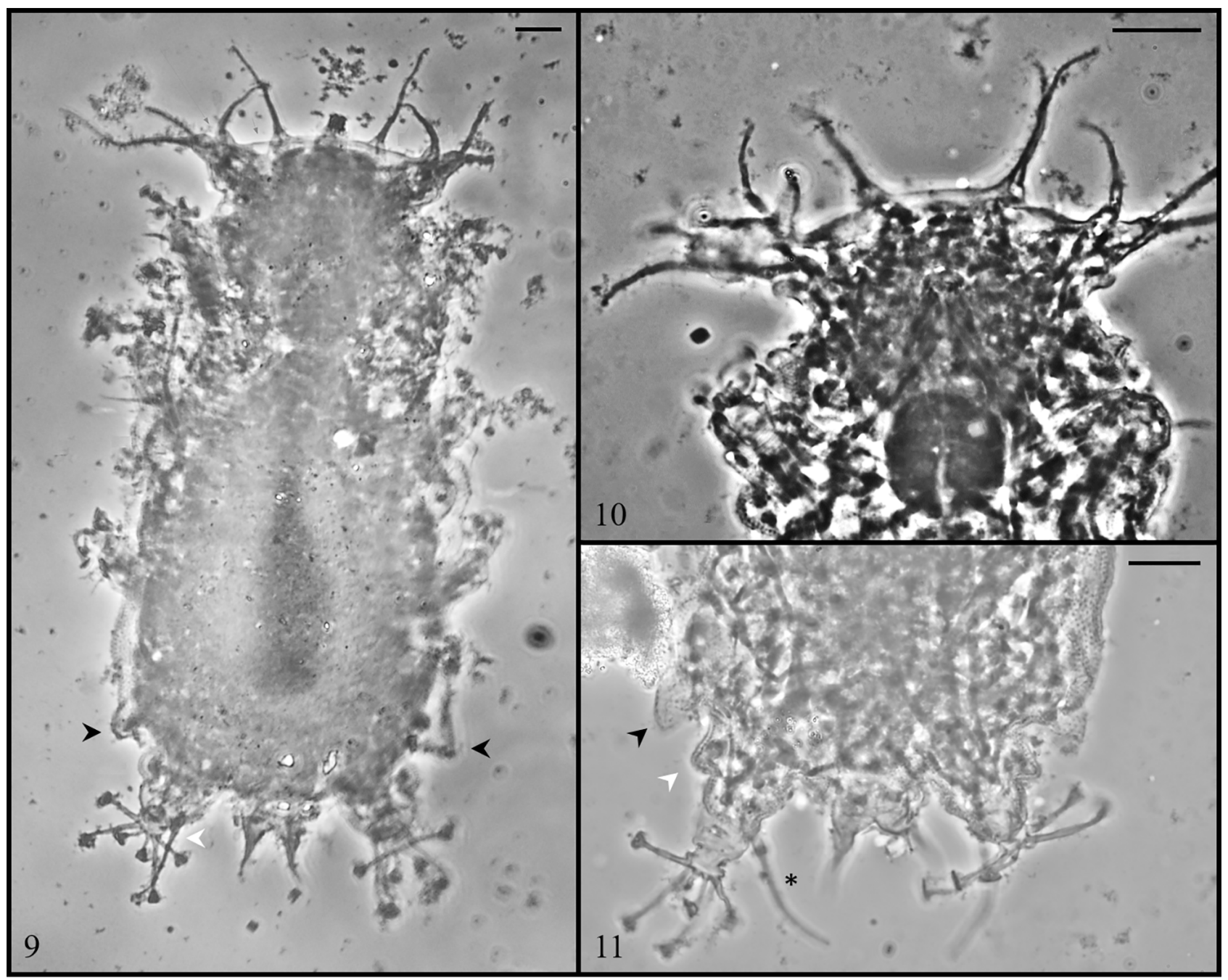

Fig. 9-11. Batillipes dicrocercus Pollock, 1970: 9, paratype. Conical body projections between legs III-IV (black arrowhead) and sense organ on leg IV (white arrowhead) are visible; 10, anterior region of a specimen showing the head and cephalic appendages. 11, posterior region of the body showing long sense organ on leg IV (asterisk), conical body projections between legs III-IV (black arrowhead) and lateral processes on legs IV (white arrowhead). Scale bars: $10 \mu \mathrm{m}$. 
and the lack of lateral processes on legs IV are differences strong enough to prevent the assignment of the specimens from the Adriatic Sea to $B$. dicrocercus. Moreover, despite variability and contrary to $B$. dicrocercus sensu stricto, in $B$. dicrocercus sensu Gallo D'Addabbo et al. caudal apparatuses can display many different aspects (they can have one, two or even more points, see fig. 2A in GALLo D'ADDABBo et al., 2000) and are not inserted into a swollen base.

Obviously, B. dicrocercus sensu McKirdy and $B$. dicrocercus sensu Gallo D'Addabbo et al. are also different species that can be easily distinguished by toe disc shape, relative toe lengths on leg IV, morphology of cephalic appendages, presence of secondary clavae, distribution of the dorsal cuticle punctation and development and shape of lateral body projections (see Tab. II).

It is interesting to note that the specimens on which the three above referred descriptions were based were found in very different ecological contexts, reinforcing the probability they belong to different species: $B$. dicrocercus sensu stricto in the intertidal from the cold temperate Northwest Atlantic; B. dicrocercus sensu McKirdy also in the intertidal but from the warm temperate Northwest Atlantic, in the transition to the tropical Atlantic; and B. dicrocercus sensu Gallo D'Addabbo et al. in the subtidal from the temperate Mediterranean Sea.

Subtidal specimens examined in this study from Rio de Janeiro and Rio Grande do Norte states, tropical Southwest Atlantic, are similar to specimens previously recorded by DA RochA et al. $(2009,2013)$ in the Brazilian states of Pernambuco, Ceará, and also Rio Grande do Norte, and attributed to $B$. dicrocercus. However, despite having a bifurcated caudal apparatus inserted in a swollen base, they cannot be assigned to any of the above descriptions attributed to $B$. dicrocercus. These specimens differ from the specimens from Massachusetts, Florida and Adriatic Sea in having a different body shape due to their protruded scapular region; evident papillary secondary clavae; very short sensorial organs on leg IV (despite longer body size) that are shorter than the sensorial spines on the other legs; oblique tarsi on the first three pairs of legs, and spatula-like toe discs (Tab. II, Figs 1, 2). In addition, Brazilian specimens can be distinguished from: (1) Batillipes dicrocercus sensu stricto by the absence of lateral processes on legs IV, by the different-shaped lateral projections that are blunt, and by having the mid-dorsal cuticular punctation smaller than dorsolateral; (2) Batillipes dicrocercus sensu McKirdy in having single tipped cephalic sensorial appendages, differentshaped lateral projections that are blunt, middle toes on leg IV equal in length, caudal apparatus inserted in a more developed swollen base, and by the absence of papillae on legs; (3) Batillipes dicrocercus sensu Gallo D'Addabbo et $a l$. in having the mid-dorsal cuticular punctation smaller than the dorsolateral punctation, different-shaped lateral projections that are blunt (conical with a distal point in $B$. dicrocercus sensu Gallo D'Addabbo et al.), and a different female gonopore that is delimited by four punctate cuticular platelets (only two in B. dicrocercus sensu Gallo D'Addabbo et al.).
Given that the specimens recorded from Brazil do not correspond to $B$. dicrocercus, we initially hypothesized that they might belong to a new undescribed species. However, when comparing the morphology of these specimens with specimens of other known species, a remarkable similarity with $B$. potiguarensis was noted (see Tab. I for morphometric data). The only difference is the caudal apparatus that in the original description of $B$. potiguarensis was noted as a conspicuous semicircle-shaped protrusion (14-23 $\mu \mathrm{m}$ long) and not bifurcated (Fig. 2). The oblique shape of tarsi on the three first pairs of legs (also present in B. spinicauda Gallo D'Addabbo, Sandulli \& de Zio Grimaldi, 2005) and dorsolateral punctations larger than mid-dorsal punctations observed in the specimens with bifurcated caudal apparatuses, were characters previously neglected by SANTOS et al. (2017) in the original description, but they are also present in $B$. potiguarensis as confirmed in this study. On the other hand, specimens of different gender and age (males were not known until now), with and without bifurcated caudal appendage, occurred simultaneously in time and space in samples from the Potiguar Basin (all specimens collected in Campos Basin had bifurcated caudal apparatuses). Otherwise, all other traits were identical among these specimens.

Ontogenetic variability of the caudal apparatus in Batillipes species has been reported by several authors (Grimaldi DE Zio \& D'AdDabbo Gallo, 1975; McKirdy, 1975; Kristensen, 1978; Morone De LuCia et al., 1988; Gallo D'AdDabbo et al., 2000; Kristensen \& MaCKNESS, $2000)$ and although a prominent key character in some species (e.g. B. phreaticus Renaud-Debyser, 1959 and $B$. bullacaudatus McGinty \& Higgins, 1968), it should be used with caution for systematic purposes. As recommended by MCKIRDY (1975) and GaLlo D'AdDABbo et al. (2000), the institution of new species should be supported in several stable traits and not in only one highly intraspecifically variable character such as the caudal apparatus. Thereby, specimens from Brazil, examined in this study, with a bifurcated caudal apparatus, with two short or long spines, sometimes displaying asymmetry, having only one short spike, or with a conspicuous more or less semicircle-shaped caudal protrusion without any spines at all, are assigned to $B$. potiguarensis, and the following emended diagnosis is provided.

Specific diagnosis of Batillipes potiguarensis (emended): Batillipes with tubular undivided primary clavae and well developed papillary secondary clavae. Cephalic cirri with swollen distal tips. Sensorial spines on all legs. Sensorial organ on leg IV very short. Legs terminated by long toes with spatula-like suction discs. Medial toes (toes 3 and 4 of legs IV of equal lengths). Three first pairs of legs with oblique tarsi with digits inserted at different levels. A distinct head separated from the body by a neck constriction. Scapular region well-developed, protruding laterally at the level of the first pair of legs. Small lateral blunt processes between legs I-III. Well-developed blunt processes between legs III and IV. Caudal apparatus exhibiting high variability: it can be bifurcated, composed of two spines inserted in a swollen 
base, in some specimens it is asymmetric with only a single small spike, or it can be a prominent more or less semicircular caudal projection without any spines. Cuticle finely but not uniformly punctated, dorsolateral punctation larger than middorsal punctation, with transverse folds. Rosette-like female gonopore delimited by four punctate cuticular platelets. Males with circular gonopore with crescent-shaped cuticular fold.

Given this study and including the correction of the records of DA RoCHA et al. $(2009,2013)$, the distribution range of $B$. potiguarensis, up till now only known from the Southwestern Atlantic Ocean, from the Brazilian states of Rio Grande do Norte and Alagoas, has been expanded in the Northern Brazilian Coast to the states of Ceará and Pernambuco, and to the Southern Coast to the state of Rio de Janeiro.

The clarification of the taxonomic status of $B$. dicrocercus Pollock, 1970 (sensu stricto) has consequences for its geographic distribution. Taking into account the need to confirm the only record outside the Atlantic Basin, from the Pacific Ocean (California, U.S.A.), based on one single specimen (Miller et al., 2014), the distribution of the species is restricted to the Northwestern Atlantic Ocean (Massachusetts, U.S.A.).

Specimens of the only record from the North of Spain that, as reported by VeIGA et al. (2009) were identified using the redescription of GALLO D'ADDABBO et al. (2000), and all the records from the Mediterranean Sea should be assigned to the unnamed species described by GALLO D'ADDABBo et al. (2000). Therefore, this unnamed species is widely distributed in the Mediterranean Basin (Adriatic Sea, Balearic Sea, Ionian Sea and Tyrrhenian Sea) and in the Northeast Atlantic Ocean (South European Shelf). We suggest that until this species is described it should be indicated as Batillipes dicrocercus sensu Gallo D'Addabbo et al.

The distribution of the unnamed species described by MCKIRDY (1975) is restricted to the Gulf of Mexico (Florida, U.S.A.). We suggest that until this species is described it should be indicated as Batillipes dicrocercus sensu McKirdy.

Acknowledgements. The authors are grateful to Petrobras S/A (Brazil) for providing samples for this study. A special thanks goes to Dr. Leland Pollock, who donated his marine tardigrade slide collection to P. Bartels. This research was partially funded by Fundação para a Ciência e Tecnologia (FCT), Portugal, through the strategic project UID/ MAR/04292/2013 granted to Marine and Environmental Sciences Centre (MARE). During this study É. Santos was supported by a doctoral grant (BEX 13580/13-2) awarded by the Program Ciência sem Fronteiras from Coordenação de Aperfeiçoamento de Pessoal do Ensino, Brazil (CAPES) and E. Gomes-Júnior by a doctoral grant (IBPG-0648-2.04/15) awarded by FACEPE (Fundação de Amparo à Ciência e Tecnologia do Estado de Pernambuco), Brazil and part by the Coordenação de Aperfeiçoameto de Pessoal de Nível Superior - Brazil (Capes) finance code 001.

\section{REFERENCES}

Accogli, G.; Gallo, M.; D’Addabbo, R. \& Hansen, J. G. 2011. Diversity and ecology of the marine tardigrades along the Apulian Coast. Journal of Zoological Systematics and Evolutionary Research 49(Suppl. 1):53-57. http://dx.doi.org/10.1111/j.1439-0469.2010.00598.x

da Rocha, C. M. C.; Verçosa, M. M.; dos Santos, E. C. L.; Barbosa, D. F.; Oliveira, D. A. S. \& SouZA, J. B. R. 2009. Marine tardigrades from the coast of Pernambuco, Brazil. Meiofauna Marina 17:97-101.

Da Rocha, C. M. C.; Santos, E. C. L.; Gomes Jr, E. L.; Moura, J. R.; Silva, L. G. S. \& BARbosA, D. F. 2013. New records of marine tardigrades from Brazil. Journal of Limnology 72(Suppl. 1):102-107.

D’Addabbo Gallo, M.; Morone de Lucia, M. R.; Grimaldi de Zio, S. \& Grimaldi de Zio, P. 1978. Nuovi dati sui Tardigradi del mesopsammon dele coste pugliesi. Thalassia Salentina 8:63-66.

D’Addabbo Gallo, M.; Leonardis, C.; Sandulli, R. \& de Zio Grimaldi, S. 2007. Further studies on the marine tardigrade fauna from Sardinia (Italy). Journal of Limnology 66(Suppl. 1):56-59. http://dx.doi. org/10.4081/jlimnol.2007.s1.56

Degma, P. \& GuidetTI, R. 2007. Notes to the current checklist of Tardigrada. Zootaxa 1579:41-53.

Degma, P. ; Bertolani, R. \& Guidetti, R. 2009-2018. Actual checklist of Tardigrada species (34th Edition: 30/06/2018). Available at $<\mathrm{http}: / /$ www.tardigrada.modena.unimo.it/miscellanea/Actual $\% 20$ checklist $\% 20$ of\%20Tardigrada.pdf $>$. Accessed on October 4th, 2018.

de Zio Grimaldi, S. \& D'Addabbo Gallo, M. 2001. Further data on the Mediterranean Sea tardigrade fauna. Zoologischer Anzeiger 240:345360.

de Zio Grimaldi, S.; Gallo D'Addabbo, M.; Sandulli, R. \& D'Addabbo, R. 2003. Checklist of the Italian marine Tardigrada. Meiofauna Marina 12:97-135.

Gallo D'Addabbo, M.; D’Addabbo, R. \& de Zio Grimaldi, S. 2000. Redescription of Batillipes dicrocercus Pollock, 1970 and revision of the genus Batillipes (Tardigrada, Heterotardigrada). Zoologischer Anzeiger 239:329-339.

Grimaldi de Zio, S. \& D’Addabbo Gallo, M. 1975. Reproductive cycle of Batillipes pennaki Marcus (Heterotardigrada) and observations on the morphology of the female genital apparatus. Pubblicazioni della Stazione Zoologica Napoli 39(Suppl.):212-225.

Grimaldi de Zio, S.; D’Addabbo Gallo, M. \& Morone De Lucia, M. R. (1983) Marine tardigrades ecology. Oebalia 9:15-31.

Grimaldi de Zio, S.; D’Addabbo Gallo, M.; Morone De Lucia, M. R. \& Grimaldi De Zıo, P. 1980. Ulteriori dati sui Tardigradi del mesopsammon di alcune spiagge pugliesi. Thalassia Salentina 10:4565.

GuidetTi, R. \& Bertolani, R. 2005. Tardigrade taxonomy: an updated check list of the taxa and a list of characters for their identification. Zootaxa 845:1-46.

Hummon, W. 1994. Trans- and Cis-Atlantic distribution of three marine heterotardigrades. Transactions of the American Microscopical Society 113(3):333-342.

KaczmareK, Ł.; Bartels, P. J.; RoszkowsKa, M. \& Nelson, D. R. 2015. The zoogeography of marine tardigrades. Zootaxa 4037(1):1-189.

KRISTENSEN, R. M. 1978. Notes on marine heterotardigrades 1. Description of two new Batillipes species, using the electron microscope. Zoologischer Anzeiger 200:1-17.

Kristensen, R. M. \& Mackness, B. S. 2000. First record of the marine tardigrade genus Batillipes (Arthrotardigrada: Batillipedidae) from South Australia with a description of a new species. Records of the South Australian Museum 33:73-87.

Maucci, W. \& Durante-Pasa, M. V. 1984. Tardigradi dela Peninsola Iberica. Miscellania Zoologica 8:67-80.

McKirdy, D. J. 1975. Batillipes (Heterotardigrada): Comparison of six species from Florida (USA) and a discussion of taxonomic characters within the Genus. In: International Symposium on Tardigrades, 1974. Memorie dell'Istituto Italiano di Idrobiologia 32(Suppl.): 177-223.

Miller, W. R.; Johansson, C. \& Adams, B. 2014. Tardigrades of North America: records for five marine species from the Pacific Coast. Transactions of the Kansas Academy of Science 117(3-4):281-286.

Morone De Lucia, R. M.; D’Addabo Gallo, M. \& Grimaldi de Zio, S. 1988. Descrizione di due nuove specie di Batillipedidae (Tardigrada: Heterotardigrada). Cahiers de Biologie Marine 29:361-373. 
Pollock, L. W. 1970. Batillipes dicrocercus n. sp., Stygarctus granulatus n. sp. and other Tardigrada from Woods Hole, Massachusetts, U.S.A. Transactions of the American Microscopical Society 89(1):38-52.

Ramazzotti, G. \& MaUCCI, W. 1983. Il Phylum Tardigrada. III. Edizione riveduta e aggiornata. Pallanza, Memorie dell'Istituto Italiano di Idrobiologia 41:1-1012.

Rodriguez-RodA, J. 1947. Contribución al estudio de los Tardigrados de España, (3). Publicaciones del Instituto de Biologia Aplicada 4:101-106.

Rodriguez-Roda, J. 1952. Tardígrados de la fauna española. Trabajos del Museo de Ciencias Naturales de Barcelona, Nueva Serie Zoológica 1(4):1-87.

Rubal, M.; Veiga, P.; Fontoura, P. \& Sousa-Pinto, I. 2017. A new Batillipes (Tardigrada, Heterotardigrada, Batillipedidae) from North
Portugal (Atlantic Ocean). Marine Biodiversity 47:921-928. DOI 10.1007/s12526-016-0526-x.

Santos, E.; da Rocha, C. M. C.; Gomes Jr., E. \& Fontoura, P. 2017. Three new Batillipes species (Arthrotardigrada: Batillipedidae) from the Brazilian coast. Zootaxa 4243(3):483-502. DOI 10.11646/ zootaxa.4243.3.4

Santos, E.; Rubal, M; Veiga, P.; da Rocha, C. M. C. \& Fontoura, P. 2018 Batillipes (Tardigrada, Arthrotardigrada) from the Portuguese coast with the description of two new species and a new dichotomous key for all species. European Journal of Taxonomy 425:1-32. DOI 10.5852/ejt.2018.425

Veiga, P.; Rubal, M. \& Besteiro, C. 2009. Primera cita de Orzeliscus belopus Du Bois-Reymond Marcus, 1952 (Tardigrada, Arthrotardigrada) para la Península Ibérica, con notas sobre otros tardígrados encontrados 